\title{
Hélio Oiticica, do samba ao rock: um relato pessoal.
}

\author{
Andreas Valentin ${ }^{1}$
}

Resumo: Dos 6 aos 13 anos, de 1959 a 1966, Andreas Valentin estudou arte com Hélio Oiticica, que Ihe ensinou técnicas de pintura, colagem com objetos encontrados e como preparar suas próprias tintas utilizando pigmentos industriais, terra, areia e cola PVA. Estimulando em seu aluno a invenção e a experimentação, esses encontros eram também um campo para a própria obra e pensamento de Oiticica.

Em 1970 reencontraram-se quando Valentin foi estudar nos EUA e Oiticica estabeleceu-se em Nova York. Em seu loft na Segunda Avenida - Babylonests - e em sua moradia seguinte - Hendryxsts - na Christopher Street, conceberam e realizaram projetos de cinema e de fotografia. As colaborações continuaram após o retorno ao Brasil em 1978 e frutificaram até sua morte em 1980.

A partir das experiências e memórias do autor, são abordados aqui alguns desses projetos, tendo como fio condutor a vivência de Oiticica na Mangueira e com o rock em Nova York.

Palavras-chave: Hélio Oiticica, New York, Mangueira, samba, rock

\section{Hélio Oiticica, from samba to rock: a personal account.}

Abstract: From 1959 to 1966, aged 6 to 13, Andreas Valentin studied art with Hélio Oiticica. He taught him painting techniques, collage with found objects, and how to prepare his own paints using industrial pigments, earth, sand and PVA glue. Stimulating his student to invent and experiment, those encounters were also a field for the artist's own work and thought.

In 1970 they reconnected when Valentin went to study in the U.S. and Oiticica had settled in New York. In his loft on Second Avenue - Babylonests - and at his next home - Hendryxsts - on Christopher Street, they conceived and carried out film and photography projects. Collaborations continued after Oiticica's return to Brazil in 1978 and carried on until his death in 1980.

The author reminisces on and recalls some of those projects having as leitmotif Oiticica's experiences at Mangueira and in New York's rock scene.

Keywords: Hélio Oiticica, New York, Mangueira, Samba, Rock

1 Pós-doutorado no Instituto de História da Arte da Freie Universität Berlin. Doutor em História Social pela Universidade Federal do Rio de Janeiro, com uma pesquisa sobre a fotografia amazônica do alemão George Huebner. Mestre em Ciência da Arte pela Universidade Federal Fluminense. Graduação em História da Arte e Cinema pela Swarthmore College, Pennsylvania, EUA. Professor-adjunto de fotografia na Universidade Estadual do Rio de Janeiro/Instituto de Aplicação. É membro da Associação Brasileira de Antropologia; em 2004 foi vencedor do Prêmio Pierre Verger de Fotografia. Em 2015, foi contemplado pela FUNARTE com o Prêmio Marc Ferrez de Fotografia. Universidade do Estado do Rio de Janeiro. E-mail: andreasvalentinrio@gmail.com. ORCID: https://orcid.org/00000001-6755-2537. Lattes iD: http://lattes.cnpq.br/5908500611293610. Rio de Janeiro, Brasil 


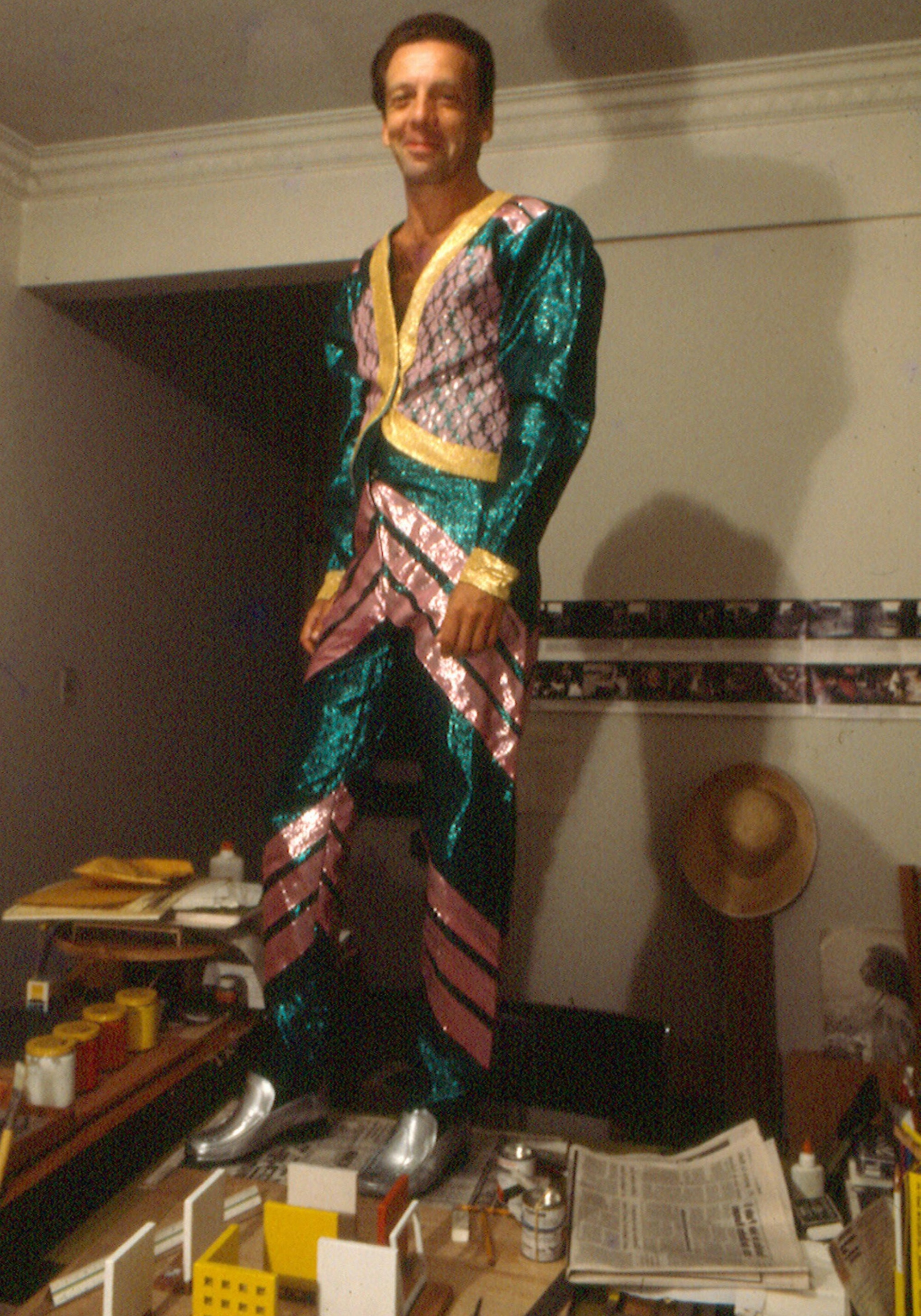


Em julho de 1975 recebi no Rio de Janeiro uma carta de Hélio Oiticica onde ele relatava sua experiência em três noites de shows dos Rolling Stones no Madison Square Garden em Nova York. Logo no início escreveu:

S T O N E S: 3 dias de STONES! Como CARNAVAL de 1 semana e q tão grandioso foi q me perdi (fudi) mas jamais creio poderei viver algo igual (o mesmo dizia quando pela primeira vez entrei com MANGUEIRA na PRES. VARGAS em 65: trovão-bateria e máximo-euforia-dança e lágrimas de entusiasmo!: inigualável!):

mesmo agora com STONES-MAD. SQ. GDEN. Em 3 dias consecutivos!: inacreditável!: 72 parece brincadeira compared to this!: foi assim como uma volta à DANÇA!: não ao MITO: à DANÇA!:

Em outros trechos comparava a energia dos shows com os ensaios e desfiles da Mangueira:

tão outra coisa q PERFORMANCE!: ENSAIO DE SAMBA ainda ME parece a melhor comparação!: ENSAIO COM VIGOR DE CARNAVAL-CONCENTRAÇÃO DE DESFILE!: já ao chegar-se ao MAD. SQ. GDEN. mil baterias ritmando quentes até q as pétalas-palco (área mais do que palco!) começassem a descer: MICK na nave-ponta da fronteira (main-petal)!: todos os outros já jamming!: GREAT MAN!: nunca visto!: o zumbir elétrico de milhões de luzes-circuitos como se fosse uma cidade toda luzente de CARNAVAL!: o mesmo zumbido q sempre ouvi-senti na PRES. VARGAS na hora do SAMBA GRANDE!: BATERIA E ZUMBIR ELÉTRICO!:

Hélio conheceu a Mangueira em 1964 levado pelo escultor Jackson Ribeiro, amigo de Lygia Pape. Ali fez amigos, conheceu as quebradas do morro, fumou maconha, encontrou a marginalidade em seu sentido mais amplo e aprendeu a sambar. No ano seguinte já seria um dos principais passistas da Mangueira, integrando a ala "Vê se Entende" da qual faziam parte também os sambistas Carlinhos do Pandeiro e Jerônimo. Hélio enfatizava que desfilava "com roupa dada pela escola" e não comprada. ${ }^{1}$ Buscando talvez um contraponto à vida burguesa da Zona Sul do Rio de Janeiro, na Mangueira ele se via "livre da parafernália intelectual de Ipanema". A vida do morro the apontara caminhos, mas não apenas os do carnaval:

"havia as noites nos botecos, os pequenos shows de subúrbio onde eu dançava para fazer finanças para a escola e todo mundo me tratava com tanta gentileza, eu me

1 Entrevista para Norma Pereira Rêgo, "Mangueira e Londres na rota, Hélio propõe uma arte afetiva". In Encontros | Hélio Oiticica, org. Cesar Oiticica Filho e Ingrid Vieira. Rio de Janeiro: Beco do Azougue, 2009, p. 99. 
sentindo como um representante da Mangueira". ${ }^{2}$

De fato, o samba e a vida na Mangueira marcaram-lhe profundamente. Foi a partir dali que desenvolveu Parangolés, a Tropicália, idealizou experiências coletivas e ambientais, como Apocalipopótese, onde a dança era forte elemento constitutivo. Em seu texto "A dança na minha experiência", de 12 de novembro de 1965, refletiu que se tratava da 'dança 'dionisíaca', que nasce do ritmo interior do coletivo, que se externa como característica de grupos populares, nações etc" onde reina a improvisação. ${ }^{3}$ Ademais, no terreiro de ensaio da Mangueira e em seu "lendário boteco 'Só para quem pode'", a dança realizava a comunhão entre a disponibilidade das "coisas" do cotidiano com o ambiente. ${ }^{4} \mathrm{E}$, quando a bateria da Mangueira começava a tocar, "era como se (Ihe) fosse dada a ordem para começar a viver"5. Assim como quando os Stones surgiram no palco da arena do Madison Square Garden, "zumbindo" eletricamente.

Naquele mesmo ano de 1964, eu já convivia com Hélio há mais de cinco anos. Em 1959, aos seis anos de idade, comecei a ter aulas semanais de arte. Uma tarde por semana, sentava-se comigo numa grande mesa em meu quarto e me ensinava técnicas de pintura com tinta a óleo e guache; mostrava como fazer colagens utilizando objetos encontrados, como páginas de revistas antigas, caixas de pasta de dentes, pedaços de tijolos e pedras; e a preparar minhas próprias tintas com pigmentos industriais, terra, areia e cola branca. Presenteou-me com livros, introduziu-me à História da Arte e artistas, do Renascimento à Modernidade.

Penso hoje que esses encontros eram, possivelmente, mais um campo para a experiência e a experimentação na própria obra do artista e em suas ideias pedagógicas. ${ }^{6}$ Os experimentos que realizei sob sua supervisão configuraram-se talvez como um desdobramento de suas práticas neoconcretas. No mesmo ano em que se iniciaram as aulas, Hélio também participou

2 Ibid.

3 OITICICA, Hélio, Aspiro ao Grande Labirinto. Rio de Janeiro: Rocco, 1986, p. 73.

4 Ibid. p. 80.

5 Hélio Oiticica, op. cit., p. 99.

6 Em 1957, Hélio, seu irmão César, Aloísio Carvão e outros artistas ajudaram Ivan Serpa a implantar o Instituto de Arte Infantil, uma escola de arte no Meier, bairro da zona norte do Rio de Janeiro. 
da fundação do Grupo Neoconcreto, com Lygia Clark, Lygia Pape, Franz Weissman, Ferreira Gullar e Amílcar de Castro.

Sempre me estimulando a experimentar, sugeriu, por exemplo, que eu trouxesse do sítio de nossa família em Teresópolis terras coloridas e areia que seriam peneiradas e misturadas com cola à base de PVA. Aplicadas nas telas, resultaram em obras onde as formas e as cores advinham da própria materialidade bruta dos elementos naturais. Ou que guardasse caixas de pasta de dentes para serem pintadas e coladas sobre a tela e, assim, investi-la de uma espacialidade para além de sua bidimensionalidade, como ele próprio já havia experimentado com seus Relevos Espaciais de 1960. Trazia para as aulas amostras dos pigmentos que utilizava nos Bólides, série iniciada em 1963. Eu misturava aquelas cores fortes - amarelos, vermelhos, azuis, roxos - com cola PVA e aplicava sobre as superfícies a tinta que eu próprio fabriquei. Hélio exigia de mim o mesmo rigor e capricho com que realizava suas obras e sempre me estimulava a seguir sua própria força motriz: "Inventa, Andreas!", dizia sempre que lhe perguntava o que deveria fazer.

Figura 1

Andreas Valentin, s.t., 1962; terra, pigmento e cola PVA sobre tela; $65,5 \times 54 \mathrm{~cm}$.

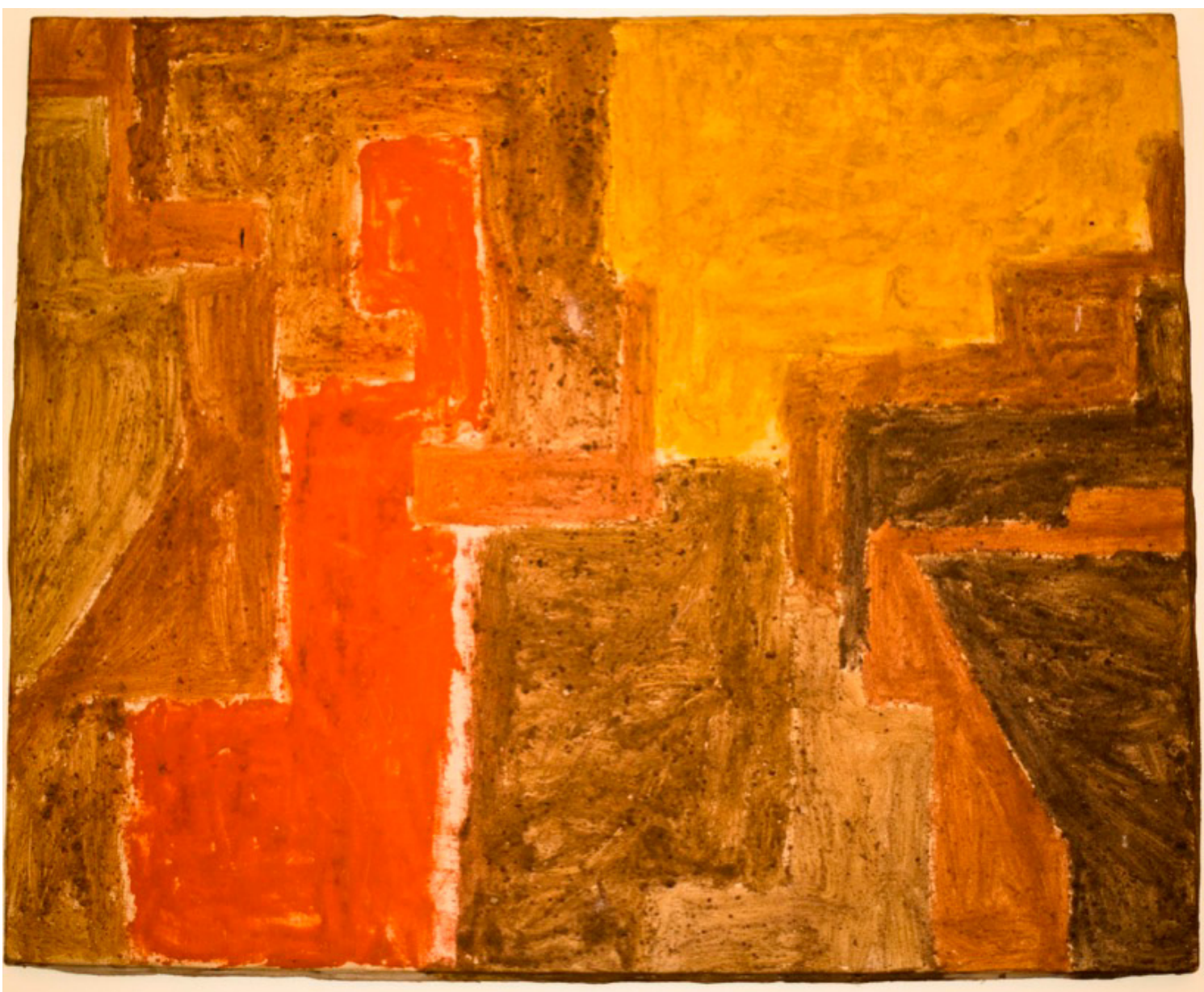


Figura 2

Andreas Valentin pintando caixas com pigmentos preparados, c. 1963 (foto Hélio Oiticica).

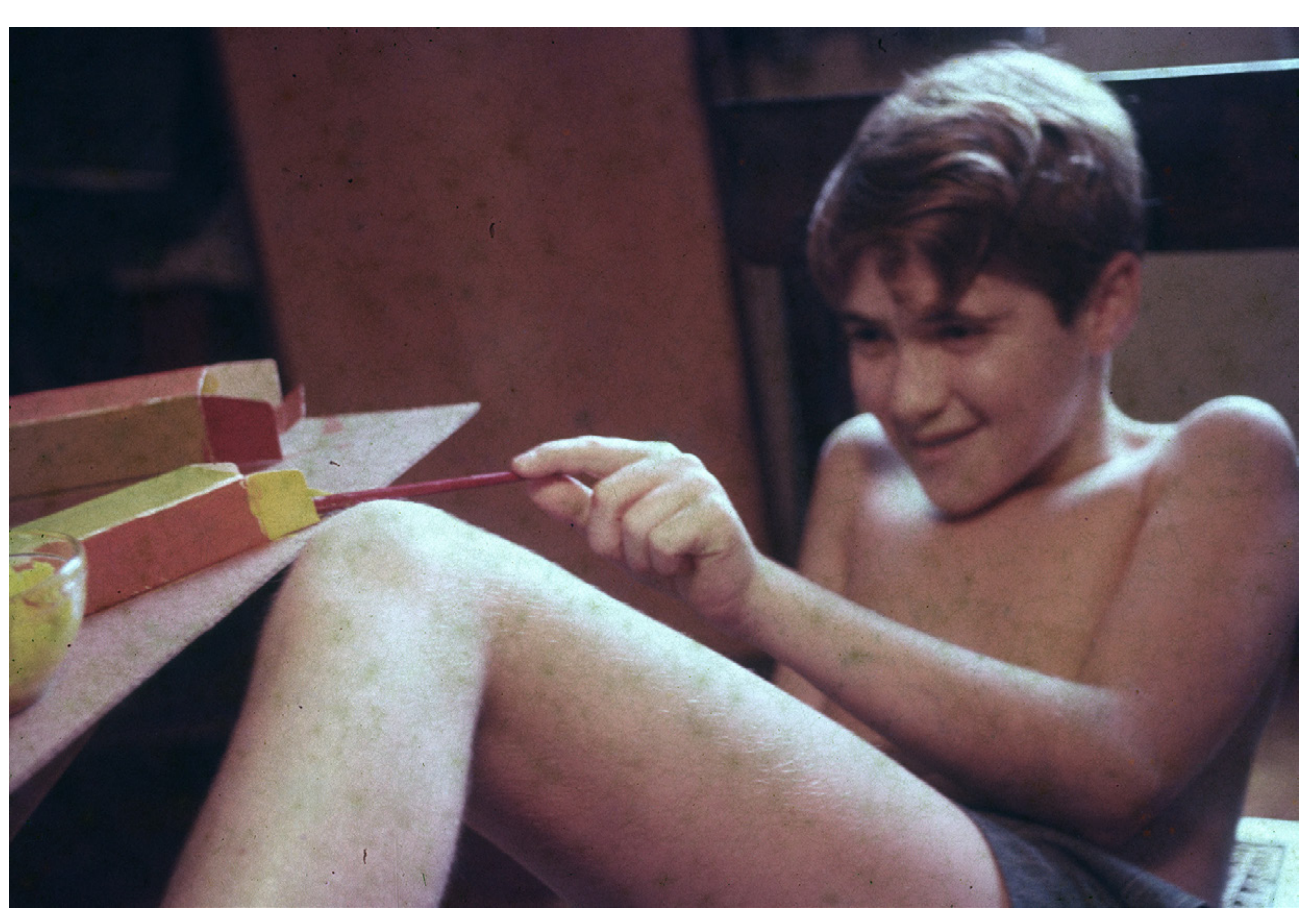

Em 1966 fui morar com meus pais em Bangkok, Tailândia. Os encontros foram interrompidos, porém o contato com Hélio foi mantido. Em julho de 1968, escreveu um texto de duas páginas datilografadas, intitulado "Andreas Valentin", no qual refletia sobre sua experiência de ensino de arte e o desenvolvimento de uma criança para a fase adulta:

Enganam-se os que pensam que dar-se às crianças tinta para pintar ou papel para cortar e colar ou massa para esculpir, ou instrumentos para tocar, seja para torna-los "gênios" no futuro. A começar que o conceito de gênio tornou-se obsoleto: todos podem ser gênios, têm a potencialidade para tal - este conceito foi criado para hierarquizar o que deveria ser privilégio coletivo: isolar o gênio, que seria o modelo de uma sociedade feudalista na origem. O tempo passou. Hoje, procura-se uma coletivização das experiências outrora reservadas aos eleitos, e nada melhor do que começá-las com o próprio crescimento numa idade quando tudo começa, cresce. Andreas Valentin foi um dos inúmeros alunos que vi crescer, talvez o único a que tenha eu acompanhado tão de perto. Desde os seis anos, quando mal sabia pegar no pincel, sua pintura cresce, devagar, mas tão real nela mesma, que muito dos seus frutos infantis chamam atenção.

[...] o que procurei foi dá-lo oportunidade: colar, pintar, principalmente experimentar. O que se verificou foi uma crescente ascensão experimental no seu "fazer artístico", por assim dizer.

[...] não interessa que deixe ou não de pintar: a criação tem n maneiras de se manifestar. Isto quis eu conscientemente lhe incutir: aprender a ver, a sentir, a experimentar. Crianças não revolucionam: crescem. $^{7}$

Eu também, é claro, cresci. Na Tailândia continuei as aulas, com o artista 
Sumpow Depphlatum. Aos sábados ia ao seu ateliê, numa "quebrada" de um bairro de Bangkok, e lá criávamos juntos. Em agosto de 1970 viajei para o Rio de Janeiro, a caminho dos EUA onde iria iniciar os estudos universitários. Em janeiro daquele ano Hélio voltara de Londres onde havia realizado sua exposição retrospectiva, "The Whitechapel Experience". Lá realizou ainda projetos com alunos na Universidade de Sussex e conviveu com outros brasileiros que se refugiavam da ditadura, entre eles Caetano Veloso, Gilberto Gil e Jorge Mautner. Conheceu o rock em show seminais, como o de Jimi Hendrix na llha de Wight. Nosso reencontro foi muito emotivo e alegre, os dois de cabelos longos e com muitas histórias para contar.

O coletivo e o individual, o público e o privado amalgamaram-se na obra e vida de Oiticica a partir de sua temporada em Londres e, definitivamente, quando mudou-se para Nova York. Em julho de 1970, viajou para Nova York para montar seus Ninhos em uma grande sala da exposição "Information" no MoMA, organizada por Kynaston McShine. Cinco meses depois, com uma bolsa de pesquisa da Fundação Guggenheim, instalava-se definitivamente

Figura 3 Hélio Oiticica no Rio de Janeiro em agosto de 1970, recebendo suas obras quando retornaram de Londres (foto Andreas Valentin).

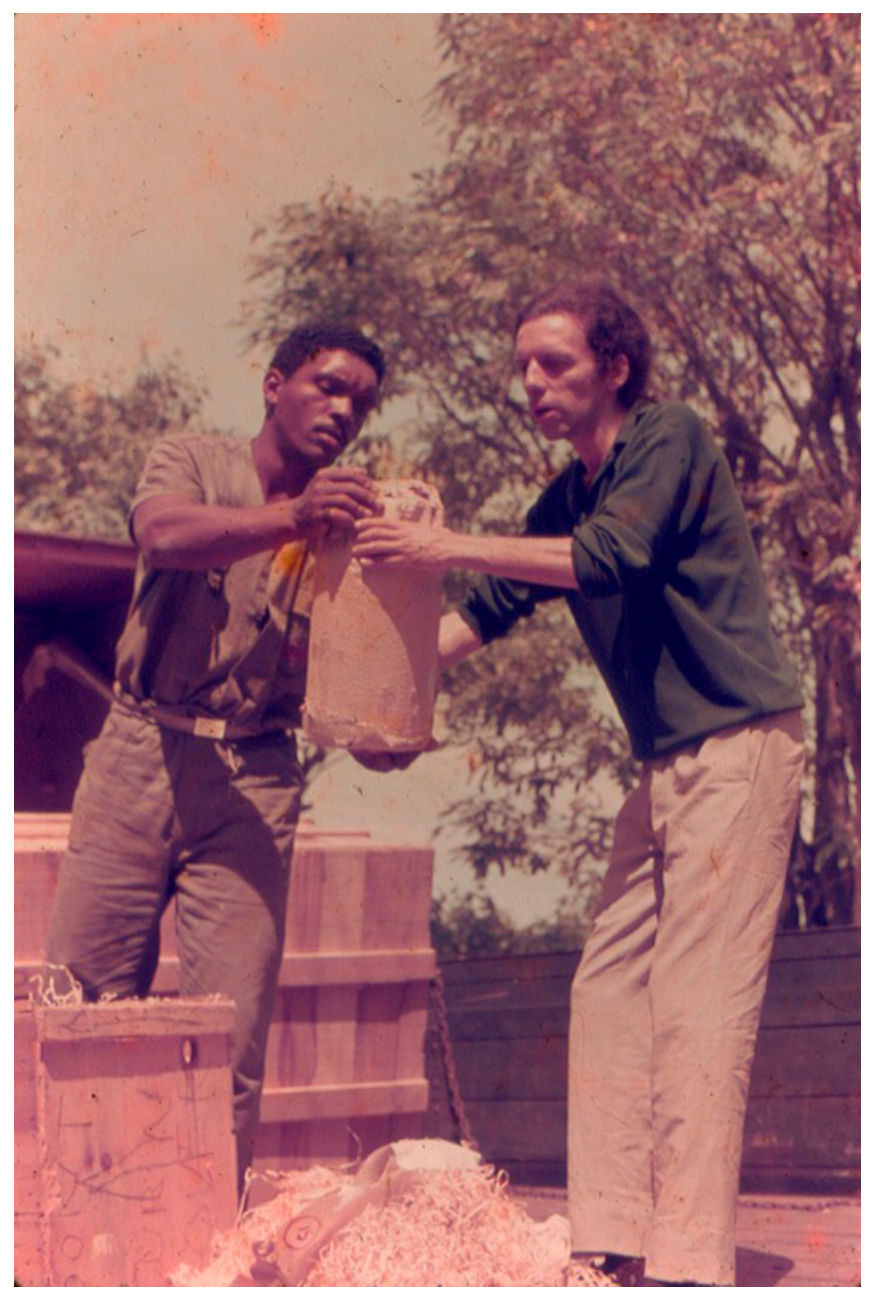


na cidade. Em carta para mim de 29/10/1970, escreveu: “logo que chegar quero ver gente de cinema underground etc.: é o que me interessa no momento; quanto às artes ditas plásticas, estou por cima em new york: recebi cartas dizendo que fui a coisa mais 'popular' na tal exposição de verão".

Os Ninhos instalados no MoMA seguiram-se aos espaços montados na Whitechapel e em Sussex. Estranhamente, Hélio não esperava tamanha "popularidade". Em carta para Lygia Clark, escrita em 16/5/1970, antes, portanto, da "Information", comentou que

[...] é loucura pensar que alguém nos States saiba muito a meu respeito; sabe como é lá; enquanto não se aparece in loco não se existe; e lugar mais central e visceral para aparecer que o MoMA de N.Y. não existe; planejei algo parecido com a coisa que fiz em Sussex, com 3 andares, tudo ninho para ficar dentro, coberto de aniagem; são vinte e tantas células; creio que será mais importante que a da Whitechapel. ${ }^{8}$

Com os Ninhos, colocava em prática ideias concebidas no ano anterior e explicitadas em "Crelazer", de 10/5/1969:

[...] O Crelazer é o criar do lazer ou crer no lazer? - não sei, talvez os dois, talvez nenhum [...] os Ninhos, no fim do Éden, como a saída para o além-ambiente, isto é a ambientação não interessa como informação para indicar algo: é a não ambientação, a possibilidade de tudo se criar das células vazias, onde se buscaria "aninhar-se", ao sonho da construção de totalidades que se erguem como bolhas de possibilidades."

De fato, esse espaço para invenção, para experiências individuais e coletivas foi um dos grandes acontecimentos da "Information". Anos mais tarde, Vito Acconci, que também participou da exposição, declarou:

no meio do Museu havia um lugar para pessoas. Isso era muito raro naquela época. Ninguém havia pensado, em termos de arte, em um espaço para pessoas. Ele estava fazendo esses pequenos compartimentos, cápsulas, ninhos onde as pessoas podiam ficar. Havia lugares no meio desse espaço público que podiam ser pequenos espaços privados [...] Desde muito cedo ele tinha uma noção muito interessante de espaço público. Não era somente para um grande número de pessoas. É um composto de espaços privados. Seu trabalho era intensamente sobre um conjunto de privacidades. Você podia ter sua privacidade e ter uma pessoa bem ao seu lado. Você podia ter um contato social e podia ter uma relação. Seu trabalho parecia ser imensamente sobre a relação entre pessoas. ${ }^{10}$

8 FIGUEIREDO, Luciano (ed.). Lygia Clark-Hélio Oiticica: cartas 1964-1974. Rio de Janeiro: Editora UFRJ, 1996, p. 145.

9 OITICICA, Hélio. Aspiro ao grande labirinto, "Crelazer". Rio de Janeiro: Rocco, 1986, p. $115,116$.

10 Depoimento para o filme Heliophonia, de Marcos Bonisson, 2002. 
ção, lazer, relações sociais e sexuais. No Loft $4^{13}$, numa área de aproximadamente $75 \mathrm{~m}^{2}$, construiu seis Ninhos. O seu ficava próximo à janela da frente do prédio. Num canto, havia uma prancheta e uma cabine/penetrável, coberta de plástico para edição de filmes Super $8 \mathrm{~mm}$. A pequena cozinha podia ser adaptada para um laboratório fotográfico. Em maio de 1971, escreveu para Lygia Clark que

o loft aqui está ficando legal: construí seis Ninhos para viver, também um troço que tem dois níveis, e por onde se entra para o de baixo, por cima; Mário [Pedrosa] ficou louco, pois quando queria falar ao telefone tinha que subir na tal plataforma; embaixo dela, fica como um subterrâneo, ou porãozinho, e tem um lugar que tem-se que rastejar para chegar; está tudo no começo, mas quero criar um lugar tão complicado-complexo que seja um mundo, sem móveis e essa coisa chata de apartamento, etc. ${ }^{14}$

Figura 5

Vista da janela do Loft 4, c. 1972 (foto Andreas Valentin).

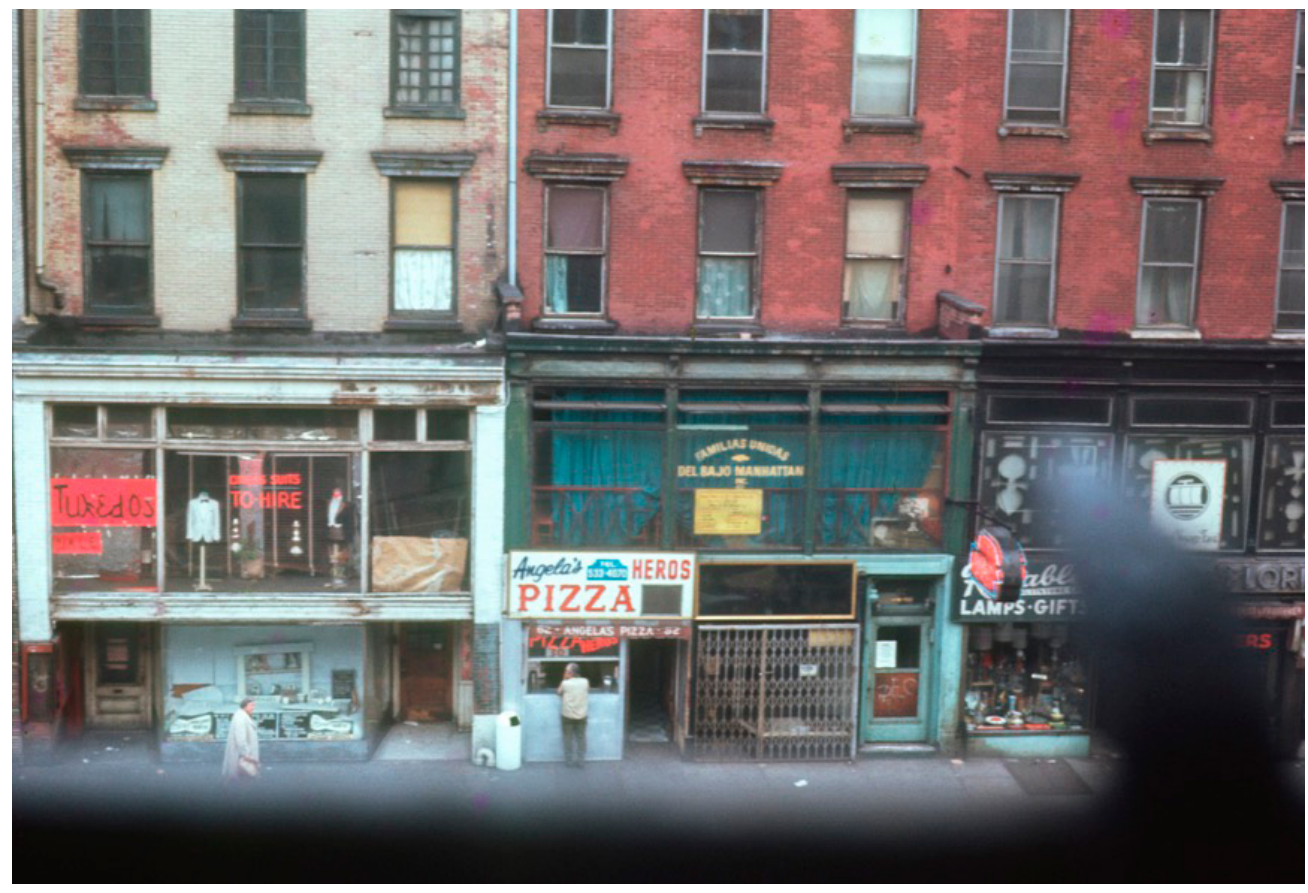

De fato, o Loft 4 tornava-se um espaço cada vez mais "complexo". Chegavam sempre pessoas; algumas, como a amiga Chris Freese (a única que tinha seu próprio Ninho, com colchão de casal); o companheiro Romero Cavalcanti; o fotógrafo Miguel Rio Branco, moraram ali por longos períodos; outras, como eu, passavam temporadas mais curtas. Meu irmão, Thomas

13 Nomeado por ele Loft 4, porque era no quarto andar de um prédio no número 81 da Segunda Avenida.

14 Ibid., p. 199. 


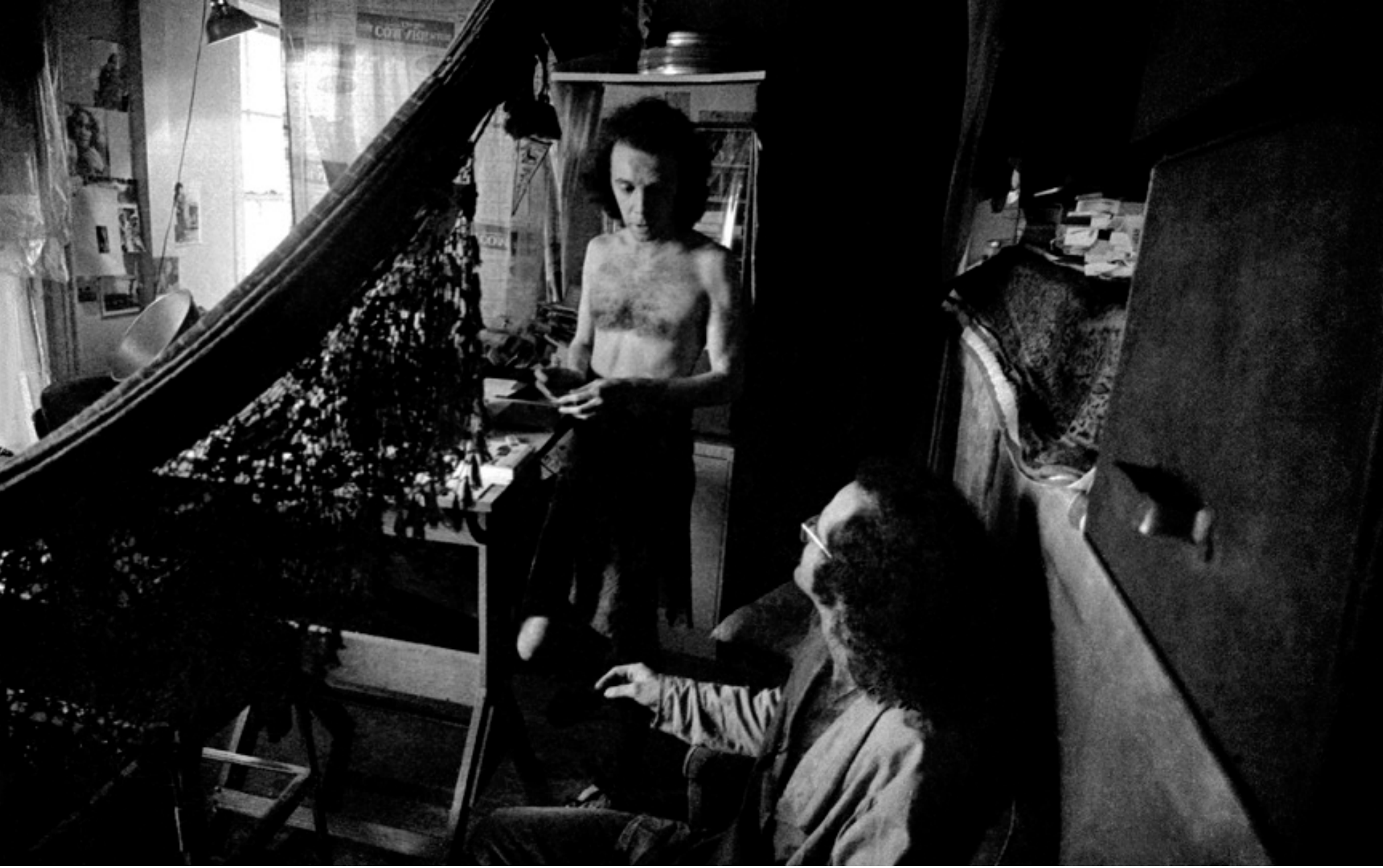

Figura 6 Hélio Oiticica e Andreas Valentin no Loft 4, 1973

(foto Thomas Valentin).
Valentin, quando em 1973 viveu em Nova York, foi também frequentador assíduo e realizou ali com Hélio a Cosmococa 6 GOAT'S HEAD SOUP. Waly Salomão, vizinho e amigo, assim relatou:

A alavanca infatigável ou mola permanente que o impelia sem parar para novas órbitas de experiências fez HO perceber que o BABYLONEST (Ninho da Babilônia) da Segunda Avenida constituía uma cidade cosmopolita compacta. Kindergarten, play-ground, laboratório, motel, boca, campus universitário contido em uma cápsula ambiental. O NINHO era provido de aparelho de TV e controle remoto zapeando sem parar, jornais, rádios, gravador, fitas cassetes, livros, revistas, telefone (o fone não sub-utilizado como mero meio pragmático mas a conversa-carretilha compulsiva com suas vívidas interjeições parecendo improviso quente de jazz, talking blues e rap), câmara fotográfica, projetor de slides, visor, caixas de slides classificados, caixas de lenços de papel, garrafas e copos descartáveis, canudos, pedra de ágata cortada em lâmina etc. etc.. NINHOS e suas estruturas de arquipélagos nem inteiriça nem linear nem insular: como uma tele-visão que transcodificasse o recôndito mais privado da vida privada em janelas abertas para os outros e para o mundo: MUNDO-ABRIGO. ${ }^{15}$

Em seus escritos, Hélio também referenciou o lugar de trabalho e de viver, como, por exemplo, nesta carta para o próprio Waly: 
[...] são CINCO

PRÁS OITO de horário daqui q é de verão (daylight) no inverno

pra economizar energia (?!)

nos meus headphones EXILE ${ }^{16}$ explode

alto: no meu NINHO a cama está desfeita e nunca penso nela

feita: scraps do mundo arrebentante q me arrebata: fragmentos

do "livro" q faço e fotos e livros/cartas/tapes/referências

do pick out diário: ANDREAS dorme e em breve estará com vocês ${ }^{17}$

Ou, ainda, aqui, para Caetano Veloso:

[...] quanto aos ninhos, gerados há tanto tempo, já passados por tantas transformações conceituais, etc., quero transformá-los teoricamente num meio de vida crelazer : aqui vamos ter para se ver tv inside, ler, dormir, odaliscar e discutir : o mito de aninhar-se. ${ }^{18}$

Sua produção em Nova York foi marcada, principalmente, pela escrita e por proposições. Em seus cadernos, em folhas manuscritas e/ou datilografadas, em esboços e especialmente em cartas para seus numerosos amigos, criou e sugeriu projetos, alguns dos quais foram realizados, enquanto outros ainda podem ser colocados em prática. Em uma carta para mim de 5/11/1973, enfatizou como era importante deixar as ideias fluírem:

porisso quando converso aqui ou proponho questionários ou trivializo sei q esta é a única maneira de puxar assuntos que se aquietaram e q quanto mais loucos e inesperados mais razão teem pra q não sejam postos de lado: falar e falar e q na maior parte sejam besteiras é ótimo: eu digo besteira à bessa".

Nas minhas frequentes visitas ao Loft 4, muitas dessas "besteiras" foram realizadas, como por exemplo, quando Hélio, Romero e eu levamos Parangolés para o metrô de Nova York. Essa ação foi fotografada, filmada e narrada no texto "CLOUDS IN MY COFFEE", escrito entre 18/2 e 6/3/1973 e enviado para Daniel Más que o publicaria:

[...] planejávamos coisas divertidas: sair de subway com CAPA de PARANGOLÉ: foi legal demais e parte de um estágio meu-PARANGOLÉ aqui: CAPAS são feitas pra específicos contatos-acontecimentos com público acidental em NOVA IORQUE: programas de circunstâncias - ROMERO o "garoto de ouro" do PARANGOLÉ é quem

16 Exile on Main Street, disco dos Rolling Stones, lançado em 12/5/1972.

17 Carta para Waly Salomão, 23/1 a 24/2/1974, NTBK 4/73, publicada na revista Polem, Rio de Janeiro, setembro/1974, p. 20-37, com fotos realizadas por mim.

18 Carta para Caetano Veloso, de 4/3/1971; Itaú Cultural, Programa Hélio Oiticica, $\mathrm{AHO} / \mathrm{PHO}$ 1099/71 
age como PROPOSITOR vestindo primeiro e dando a CAPA pras pessoas vestirem: filmamos (ANDREAS VALENTIN q tem 20 anos e conheço desde os 6 quando ensinava pintura no tempo em que ainda existia pintura, é quem filmava em $16 \mathrm{~mm}$ algumas sequências do encontro no subway da NEW LOTS AVE.). ${ }^{19}$

Em 26 de julho de 1972, dia em que Hélio e Mick Jagger celebram seus aniversários, fomos juntos assistir ao concerto dos Rolling Stones no Madison Square Garden. Nesse mesmo dia, gravei no metrô um áudio em fita cassete, que seria utilizado no Projeto Filtro, proposto para ser executado

Figura 7

Página do Cader-

no NTBK $4 / 73$

$(\mathrm{AHO} / \mathrm{PHO}$

0318/74)

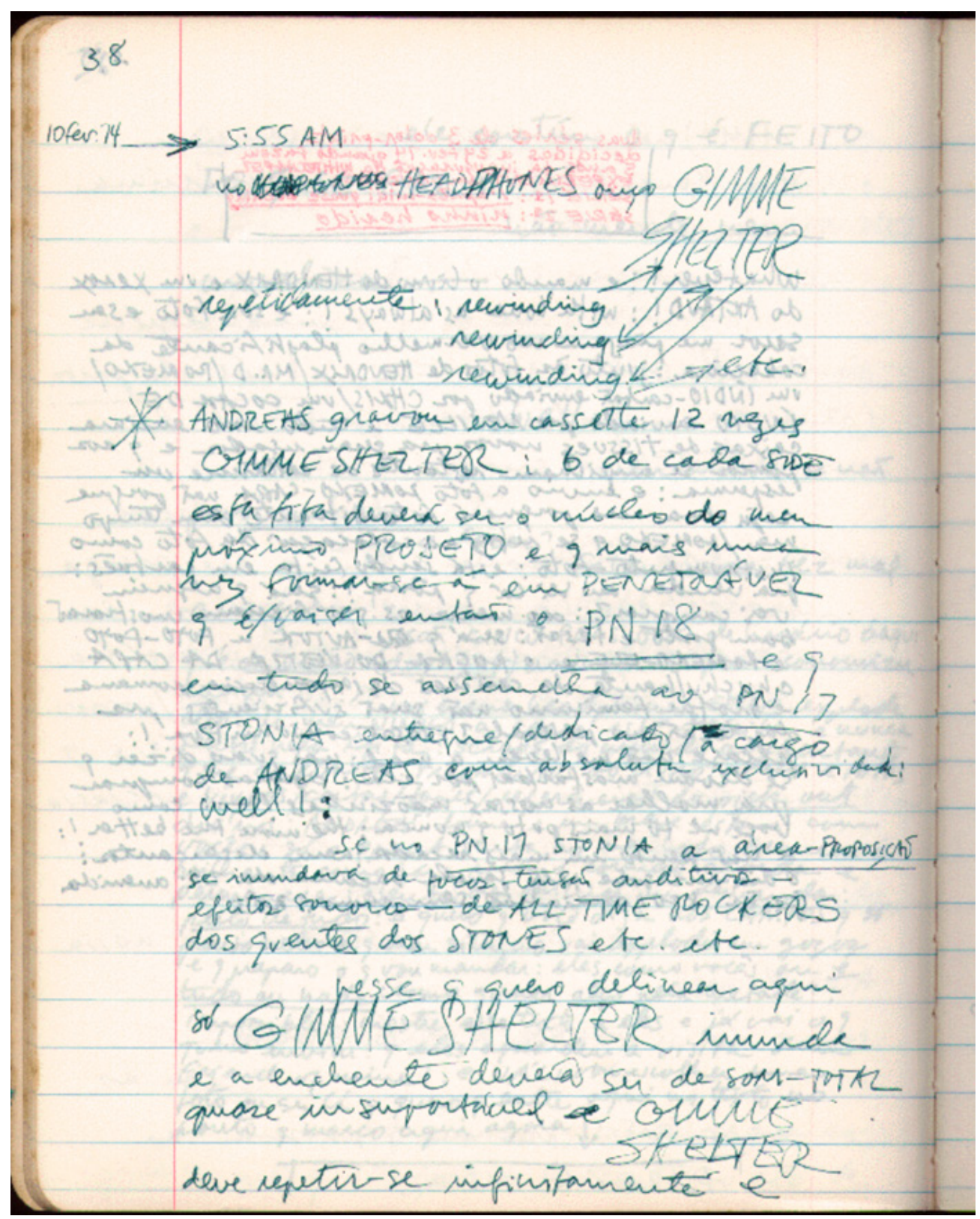

19 Itaú Cultural, Programa Hélio Oiticica, AHO/PHO 0481/73 
por Carlos Vergara no Museu de Arte Moderna do Rio de Janeiro. Dois anos depois, Hélio me pediu para gravar a música Gimme Shelter dos Rolling Stones doze vezes, seis de cada lado de uma fita cassete de 60 minutos. Ouvindo-a, em 10/2/1974 esboçou a proposta do Penetrável PN 18 SHELTER SHIELD, semelhante ao Penetrável PN 17 STONIA, projetado em janeiro e dedicado a mim. Marcadamente presente em suas ideias, no ano anterior anotara que Gimme Shelter "não é música cantada e está mais radicalmente afastada de qualquer canto: é grito q é de multidão: marcha vitoriosa pelas ruas experimentais da liberdade". ${ }^{20}$

No Loft 4 Hélio refletiu sobre, desenvolveu e realizou experiências radicais com a imagem, resultando em obras, como, por exemplo, as projeções Neyrótika e Helena inventa Ângela Maria; as Cosmococas; o filme Agripina é Roma-Manhattan; e sua concepção de quasi-cinema. Como Jack Smith, com suas performances/instalações multimídia realizadas em seu loft e que causaram grande impacto no artista, ele também, em seu ambiente privado, praticou um cinema ao vivo, em constante fazer.

Em fevereiro de 1974, fiz um filme com Hélio no escritório de tradução All-Languages, onde ele trabalhava desde 1972, após o encerramento da Bolsa Guggenheim. Seu expediente ali era de madrugada, numa das quais eu o acompanhei. O filme (3'20", Cor) retrata o ambiente fora do comum, comandado por Mrs. Besner que, pelo microfone em sua sala, disparava ordens para sua equipe. Hélio foi por ela apelidado de "Lightning" (Relâmpago), por causa de uma camiseta que gostava de usar. Em carta escrita para mim em 31/03/1974, comentou sobre o filme:

gostei muito; não creio que devam ser montados cortando: apenas emendar um no outro: os cortes dos takes e os framings têm uma curiosa justeza: muito bons: é incrível $q$ as pessoas se mostram por frestas: são mais o desconhecido delas do q o $q$ apresentam imediatamente: BESNER está louquíssima: misto de professora de ginástica e freak-demônio: sobrancelhas diabólicas acima dos óculos-máscara: FRANCO se encolhe freak-PRIMA pelas frestas das portas e dos cantos revelados: LILLY sempre mãos q furam espaços-ar: estranhíssimo: até eu estou no q não me conheço: inflado de loucura e demon life: tanned não de sol.

Dois meses depois retornei ao Rio de Janeiro. As ideias e projetos continuaram fluindo através de extensas cartas e longos telefonemas internacionais - falávamos de graça, pois havíamos descoberto um sistema que 
Figura 8

Still do filme All-Languages, 1974.

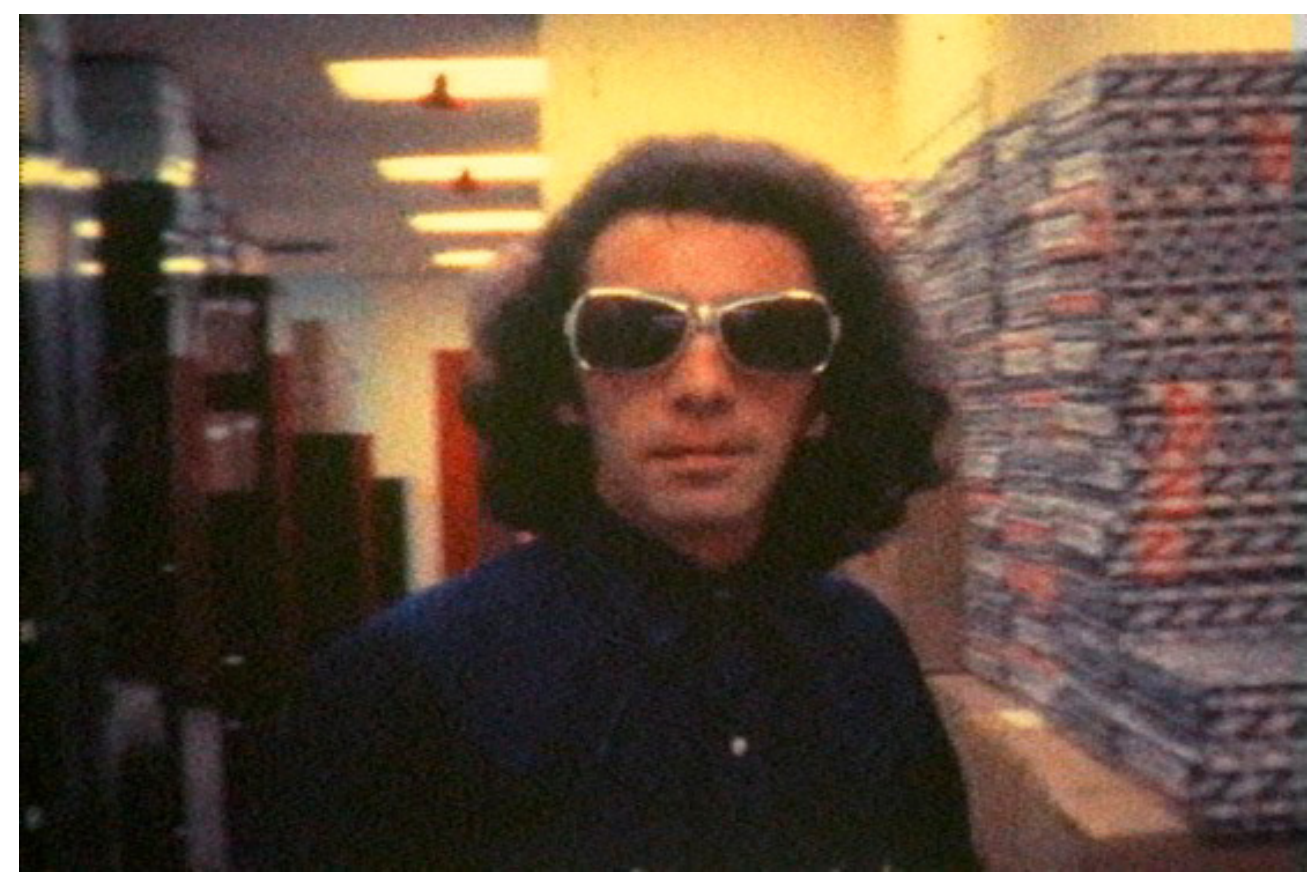

nos permitia utilizar cartões de crédito da própria empresa telefônica ATT. Em agosto realizei com Thomas Valentin o filme Círculo Vermelho sobre o Branco (7'38", Cor). Em uma longa sessão contínua de filmagem, a obra mostra o corpo de Thomas sendo inteiramente pintado de branco. Embora não tenha sido executado em parceria direta com Hélio, esse trabalho relacionava-se com sua obra e seu pensamento.

Em 1974, desenvolvemos ainda o projeto Call me Helium, com o qual pretendíamos homenagear no Rio de Janeiro nosso amigo em Nova York. Um grande balão vermelho inflável seria içado no Pier da praia de Ipanema e performances seriam realizadas de acordo com proposições enviadas por Hélio. $^{21}$

Em novembro de 1974, depois de ter sido assaltado no Loft 4, Hélio mudou-se para um apartamento bem menor, na Christopher Street, West Village. Lá, adaptou seus Ninhos para esse espaço reduzido, renomeado Hendrixsts. Meu irmão e eu o visitamos no final daquele ano e novamente no seguinte. Realizamos ali três filmes, One Night on Gay St., Flit e pHOne.

21 Por vários motivos, Call me Helium não pode ser realizado naquela época. Foi executado, no entanto, em 2014, com performances na Praia de Ipanema e no Centro Cultural Correios, onde também foi montada uma exposição sobre o projeto. O poeta Jorge Salomão, falecido em 2020, foi um dos protagonistas. 


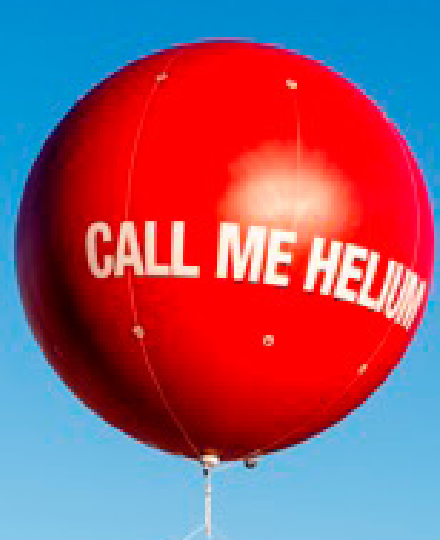

Figura 9 Call me Helium, praia de Ipanema, 2014 (foto Andreas Valentin).

One Night on Gay St. (5'21', PB) foi filmado em uma noite fria de inverno nova-iorquino num beco escuro (Gay Street) próximo à casa do artista. Ele é Mike the Addict (Mike, o viciado), um dos protagonistas ao lado de Thomas Valentin (Colombo the Man - o Homem), Luiz Carlos Joels (Charlie the Hustler - o avião) e Waly Salomão (um inocente transeunte). Longas conversas e discussões antecederam a produção que, embora não tenha sido roteirizada plano a plano, foi pensada como uma narrativa sequencial para ser filmada em estilo Cinema Noir utilizando apenas a iluminação de rua. Quando voltei para o Rio de Janeiro, montei o filme numa moviola Super 8 e enviei uma cópia para Hélio em Nova York.

O texto de Hélio Algo quase-Genet ${ }^{22}$, escrito em agosto de 1973 , foi a base do filme Flit (3'20, PB). Ali, ele narra a morte de Oto, pai da amiga e passista da Mangueira, Rose. Oto era traficante do Morro do Estácio e, supostamente, morreu de uma overdose de cocaína que lhe foi aplicada por

22 Itaú Cultural, Programa Hélio Oiticica, AHO/PHO 0401/73 e em OITICICA, Hélio, Conglomerado Newyorkaises. Rio de Janeiro: Beco do Azougue, 2013, p. 132-135. 
Figura 10

Still de One Night on Gay St.: Hélio

Oiticica e Luiz Carlos Joels, 1975.

Figura 11

Still de Flit, 1975.
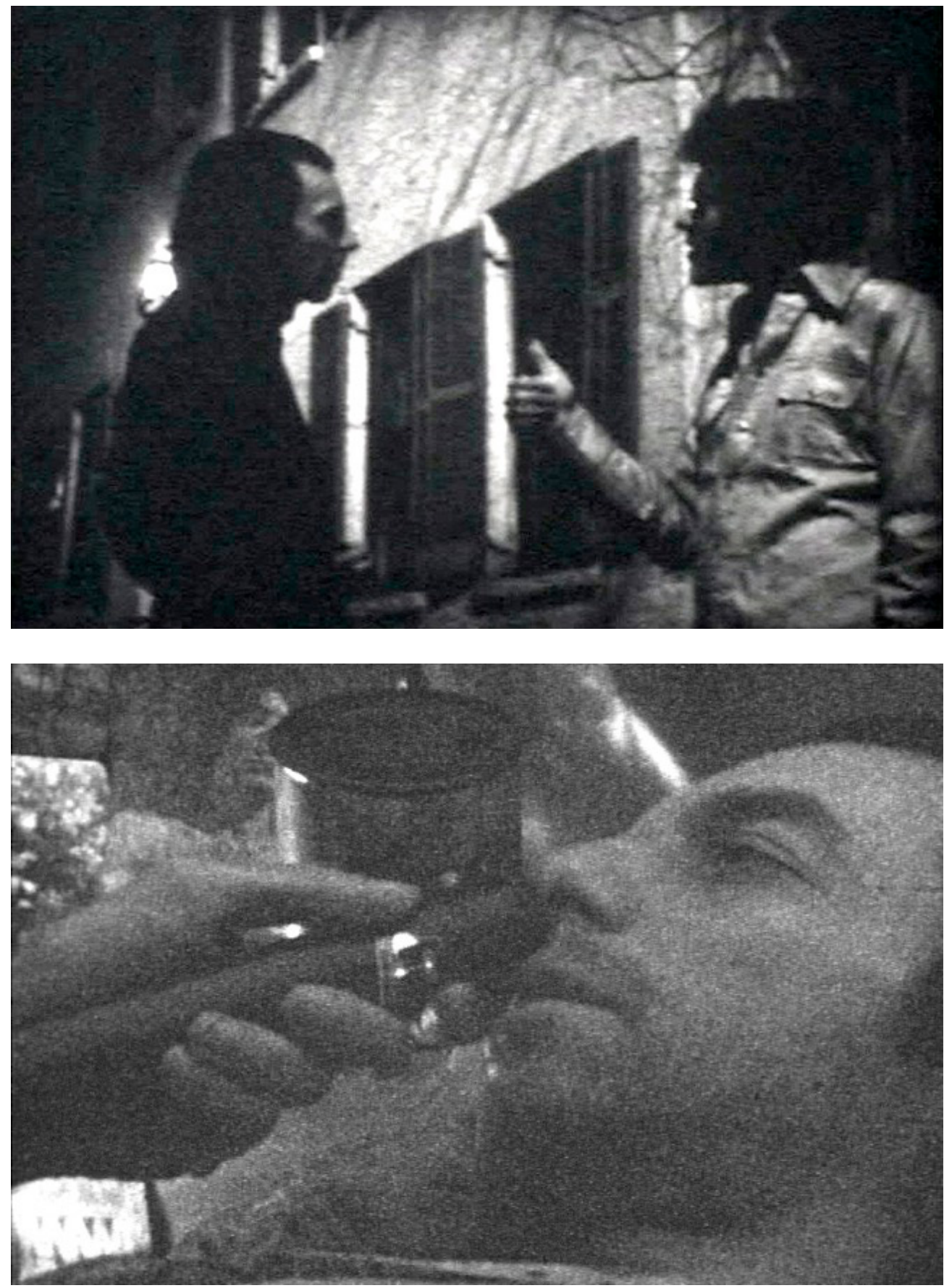

uma bomba de flit ${ }^{23}$. Hélio ouviu essa história de sua amiga Chris Freese e escreveu uma reflexão sobre o estado alterado provocado pela cocaína, abordando ainda questões de raça, vida e morte.

23 "Flit" era uma marca tradicional brasileira de inseticida, numa época quando esse produto ainda não vinha acondicionado em latas de aerossol. Para ser utilizado, era necessário despejá-lo num pulverizador, chamado de "bomba de flit". 
Thomas e eu realizamos, inicialmente, uma série de fotografias da bomba de flit - o "gadget" - que enviamos em maio de 1974 por correio para Hélio, depois que ele as havia cobrado em carta de 28/4/74: "as tais pump-photos q estavam vindo estavam mesmo? for chrissake!". Ele pretendia utilizá-las em um Bloco-Seção do livro que planejava, Conglomerado Newyorkaises. No final do ano, levamos a bomba conosco e filmamos Flit nos Hendrixsts em planos-sequência editados diretamente na câmera.

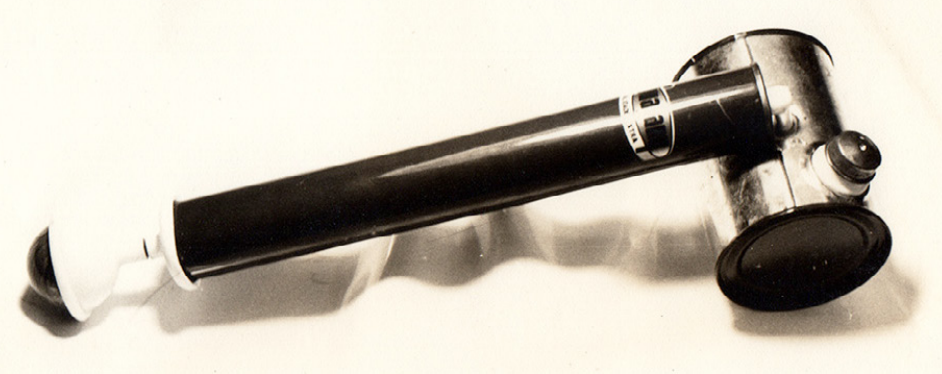

Figura 12

Bomba Flit, 1974

(foto Thomas

Valentin)

Em pHOne (2'24", Cor), um Super 8 sonoro, Hélio fala ao telefone com Waly, enquanto a câmera vagueia pelo espaço de trabalho revelando a TV e a maquete de um penetrável pentagonal.

Em fevereiro de 1978, após ter sido assediado pela imigração americana por suas preferências sexuais, Hélio retornou ao Rio de Janeiro. Fui busca-lo no aeroporto e ele veio morar comigo no Leblon. Três meses depois mudou-se para o apartamento da amiga Sonia Miranda na Rua Carlos Góis, bairro do Leblon. Energizado por sua volta à cidade, pelo contato pessoal com velhos amigos e lugares, pelas homenagens da mídia, de volta ao Brasil ele "começava", como enfatizou na entrevista para Cleusa Maria 
no Jornal do Brasil: "tudo o que fiz antes, considero um prólogo"24. Interessou-se novamente pela materialidade dos objetos, pelos espaços públicos ao ar livre e a arquitetura do Rio de Janeiro. E buscou seus conhecidos no submundo carioca:

a primeira coisa que fiz quando cheguei foi visitar uns amigos que moram no Mangue. ${ }^{25}$ Quase me perdi no meio dos viadutos, e para chegar aonde queria tive de seguir um grupo de travestis. Mas acho maravilhoso tantos viadutos. Fui também ao morro da Mangueira reencontrar meus amigos, pois não posso passar sem o mundo da malandragem. ${ }^{26}$

Ainda sobre a Mangueira, disse:

Em Nova York me perguntavam: "não tem saudade da Mangueira? E do Rio?" Eu respondia que não posso ter saudades da Mangueira porque sou a Mangueira. Não sentia saudades, porque comi a fruta inteira. Saudades só sente quem deu apenas uma dentada. ${ }^{27}$

Pouco depois de chegar, Hélio e eu fizemos uma obra, o Parangolé Jornal: três páginas abertas do Jornal do Brasil, plastificadas com cola PVA. O Parangolé foi "vestido" por seu sobrinho Luiz Antonio Salgado e fotografado por mim na praia do Leblon junto ao último posto de salvamento da orla da Zona Sul ainda com sua arquitetura original que lembra as obras neoplasticistas do arquiteto J. J. P. Oud. Essa série de vinte imagens seria publicada no próprio Jornal do Brasil, ilustrando a primeira matéria sobre ele após sua volta. ${ }^{28} \mathrm{Em}$ entrevista a Lygia Pape para a Revista de Cultura Vozes, ele reforçava a ideia de se fazer algo para ser fotografado, como ele já vinha fazendo com parte de sua produção em Nova York:

[...] essa necessidade de fazer alguma coisa para ser fotografada, desencadeia algo. O Parangolé, que eu e Andreas Valentin fizemos para ser fotografado para a reportagem de um jornal,

24 Cleusa Maria, "Hélio Oiticica está de volta”, publicada no Jornal do Brasil em 8/3/1978. In Encontros | Hélio Oiticica, org. Cesar Oiticica Filho e Ingrid Vieira. Rio de Janeiro: Beco do Azougue, 2009, p. 169.

25 O Mangue era a zona de prostituição do Rio de Janeiro. Sua amiga Rose, também passista da Mangiera morava ali. No final dos anos 1970 a região foi renovada.

26 Ibid., p. 169

27 Ibid., p. 170

28 A matéria (entrevista para Cleusa Maria) foi ilustrada não com a série que fizemos, mas com uma fotografia realizada pelo fotógrafo do jornal, Luiz Carlos David. 
Figuras 13 e 14 Hélio Oiticica e Andreas Valentin, Parangolé Jornal, 1978. Jornal e cola PVA. (fotografias Andreas Valentin) deveria ser de uma matéria especial que contrastasse com a cor azul do posto de salvamento escolhido como cenário. Usamos jornal, a textura do jornal deu o resultado esperado. ${ }^{29}$
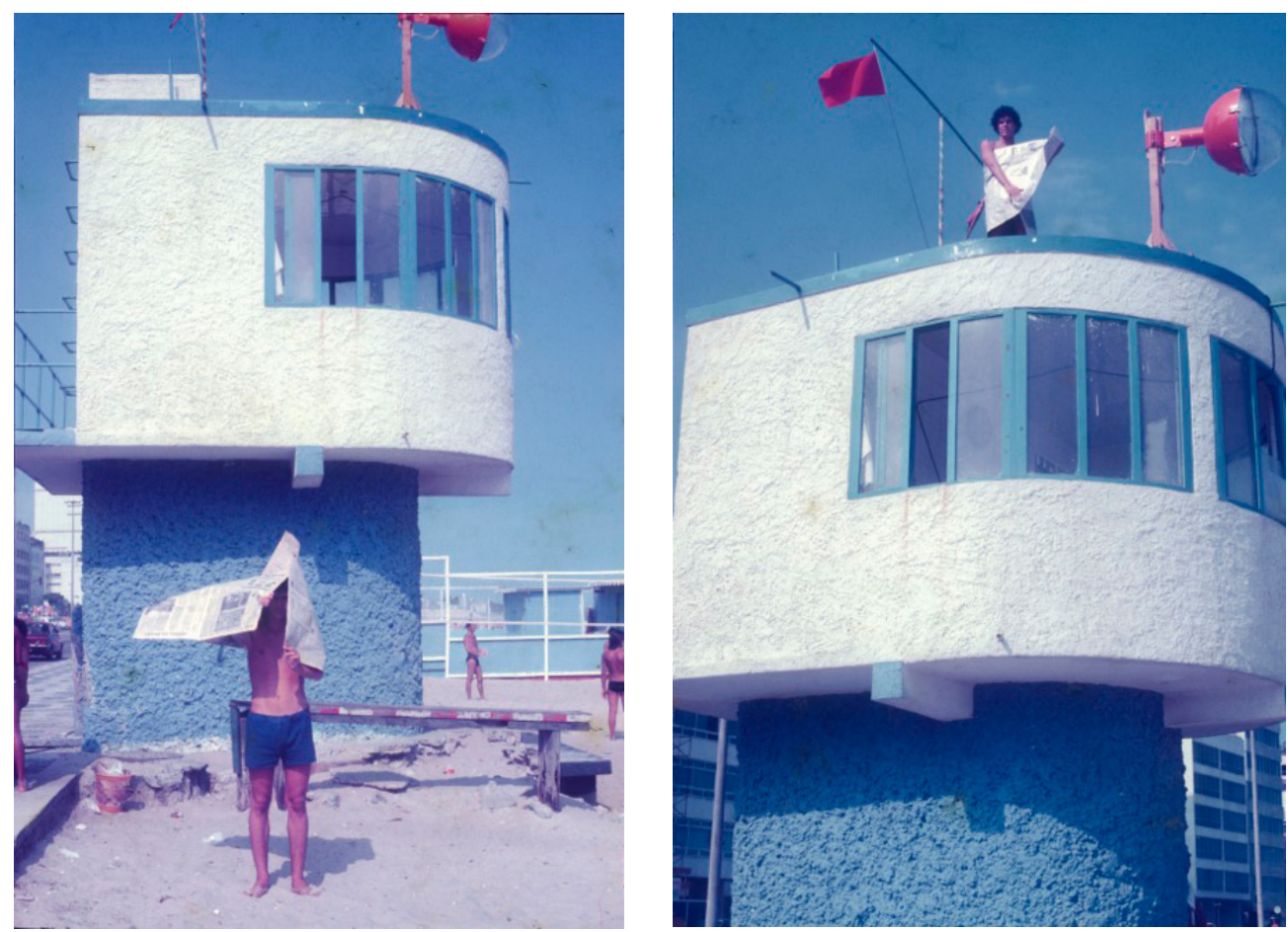

Hélio viveu intensamente os dois anos que morou no Rio de Janeiro até sua morte prematura, aos 43 anos, em março de 1980. Trabalhou em vários projetos ao mesmo tempo - maquetes, projetos de penetráveis, proposições; colaborou em filmes de seus amigos; escreveu para jornais e revistas; cuidou de sua saúde. Participei ativamente desse movimentado cotidiano, encontrando-o frequentemente para fotografar obras e auxiliar em projetos (tudo que Hélio fazia tinha um sentido de "obra") como, por exemplo, buscar pedaços de asfalto na obra do metrô no Rio de Janeiro; ir à praia da Barra coletar areia branca para montar o piso de maquetes; ou apenas conversar, trocar ideias, conectar. Hélio sempre foi um artista antenado com o mundo ao seu redor.

Numa noite fria de agosto, Hélio me telefonou e perguntou se poderia acompanha-lo pra buscar pedaços de asfalto na Av. Presidente Vargas no

29 Lygia Pape, “Fala Hélio", julho de 1978. In Encontros | Hélio Oiticica, org. Cesar Oiticica Filho e Ingrid Vieira. Rio de Janeiro: Beco do Azougue, 2009, p. 184. 
Rio de Janeiro, que estava em obras para a construção do metrô. Essas peças materializaram-se em MANHATTAN BRUTALISTA / AV. PRES. VARGAS - KYOTO/GAUDI. Em bilhete para Daniel Más escreveu que

esse troço com que fui fotografado é MANHATTAN BRUTALISTA apropriado da AV. PRES. VARGAS numa noite de expedição para apanhar escombros da antológica avenida: trouxe-os para casa: é como um objet-semimágico-trouvé e parte de uma experiência do mito desmitificado: instalei uma espécie de jardim transformável no banheiro do estúdio ( $q$ agora está sendo mudado para outro apê) q faz pensar em Kyoto, no Japão, e nosso Gaudi, o genial arquiteto d'ESPAÑA ${ }^{30}$

Figura 15

Hélio Oiticica

buscando peças de asfalto na Av. Presidente Vargas, Rio de Janeiro, 1978 (foto Andreas Valentin)

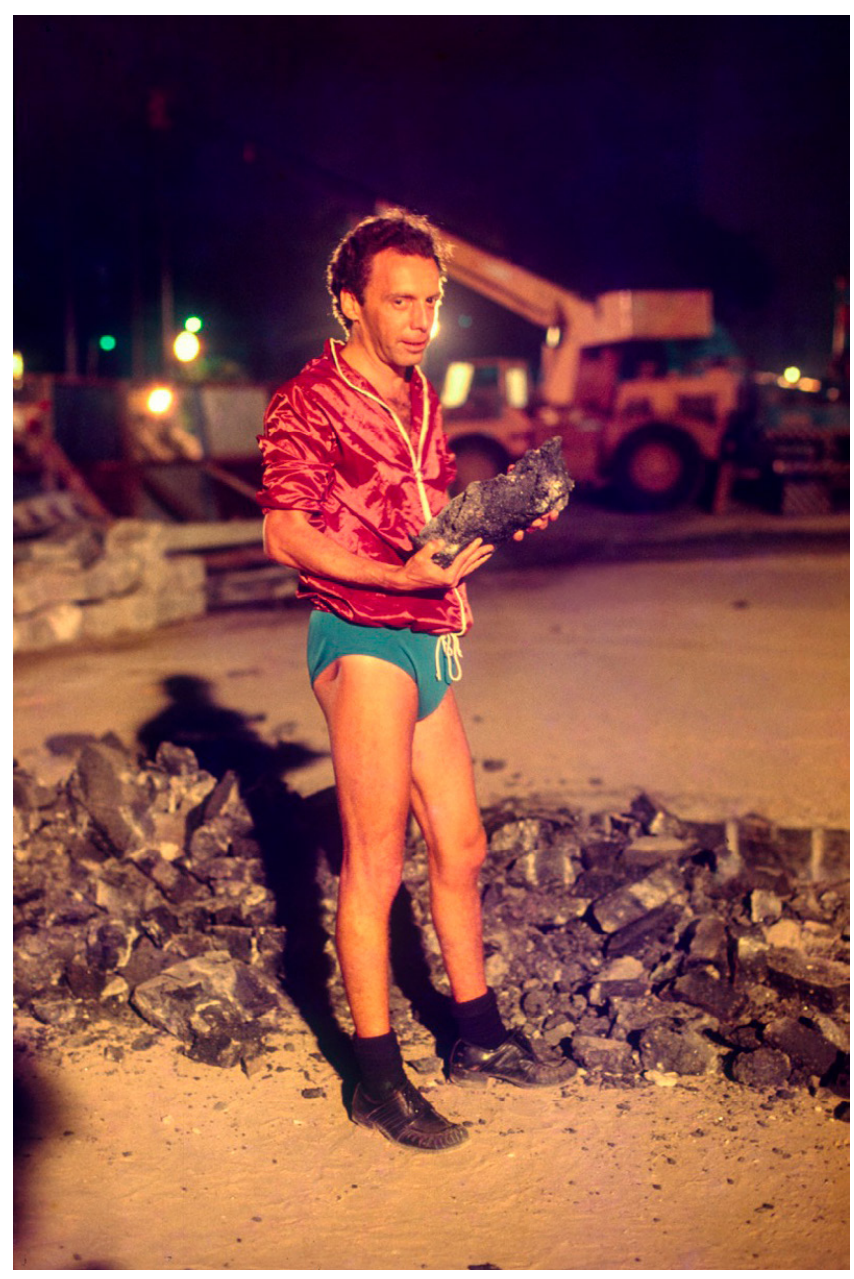

É interessante lembrar que a ideia desse projeto já havia sido pensada por ele em 1966. Em seu texto "Programa Ambiental", escreveu que tinha

30 Itaú Cultural, Programa Hélio Oiticica, AHO/PHO 0074/78 
um programa, para já, "apropriações ambientais", ou seja, lugares ou obras transformáveis nas ruas, como, p. ex., a obra-obra (apropriação de um conserto público nas ruas do Rio, onde não faltam, aliás - como são importantes como manifestação e criação de "ambientes, e já que não posso transporta-las, aproprio-me delas ao menos durante algumas horas para que me pertençam e deem aos presentes a desejada manifestação ambiental).

Em 1979, fiz fotografia de cena para o filme $\mathrm{HO}$ de Ivan Cardoso. Para as filmagens na Mangueira a produção levou vários Parangolés e alguns Bólides. Foi uma verdadeira apoteose! Amigas e amigos de Hélio dançavam nas quebradas do morro como se estivessem na Avenida. Apesar da paisagem da favela ter mudado muito - os velhos barracos de madeira já começavam a dar lugar a casas de alvenaria - Hélio estava ali totalmente à vontade.

Figura 16 Hélio Oiticica, Nininha com $\mathrm{Pa}-$ rangolé $P 8$ Capa 5 , Homenagem à Mangueira, 1965.

(foto Andreas Valentin, 1979)

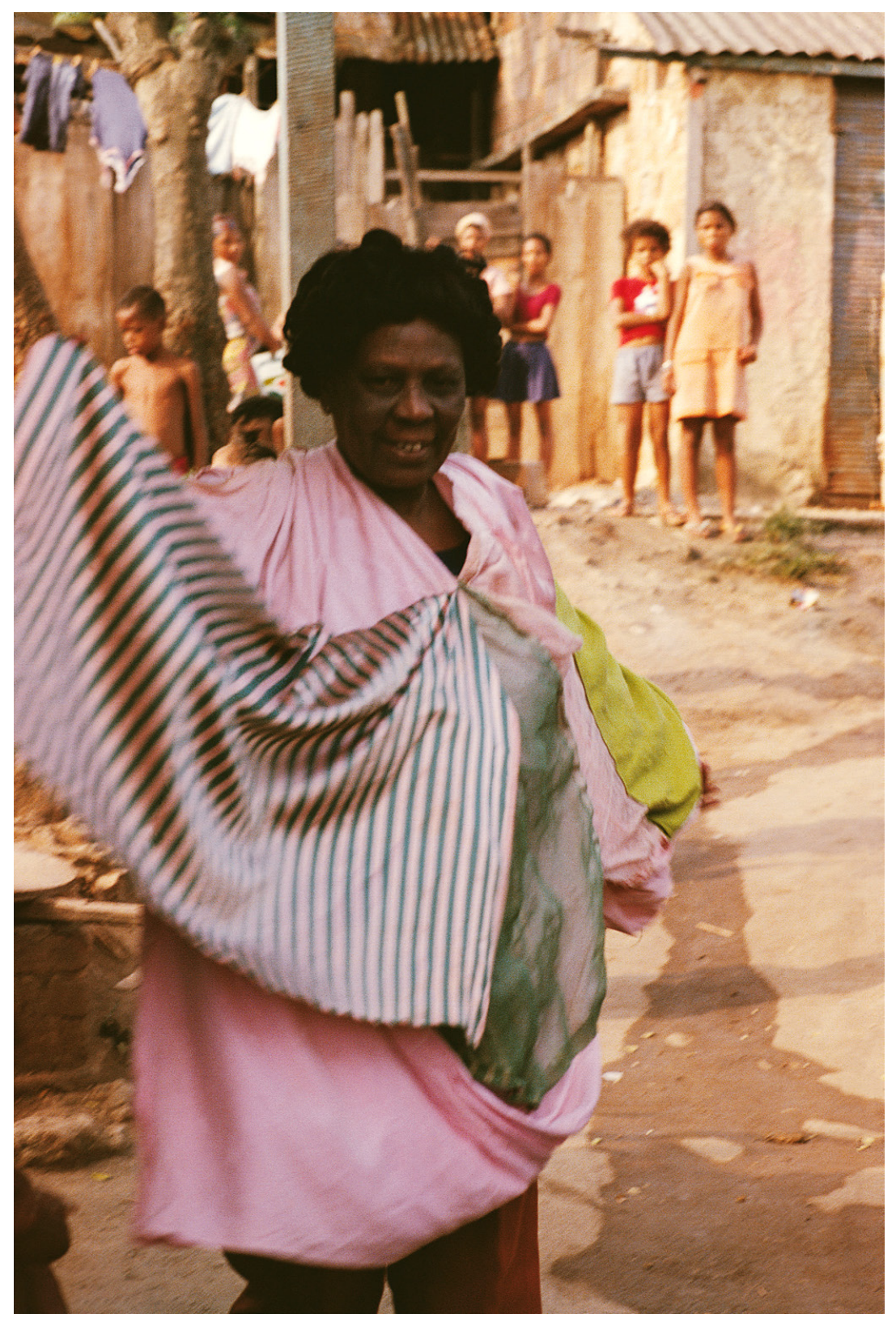


Figura 17

Hélio Oiticica, BOL 09 Bólide Caixa 8, 1964.

(Foto Andreas Valentin, 1979).

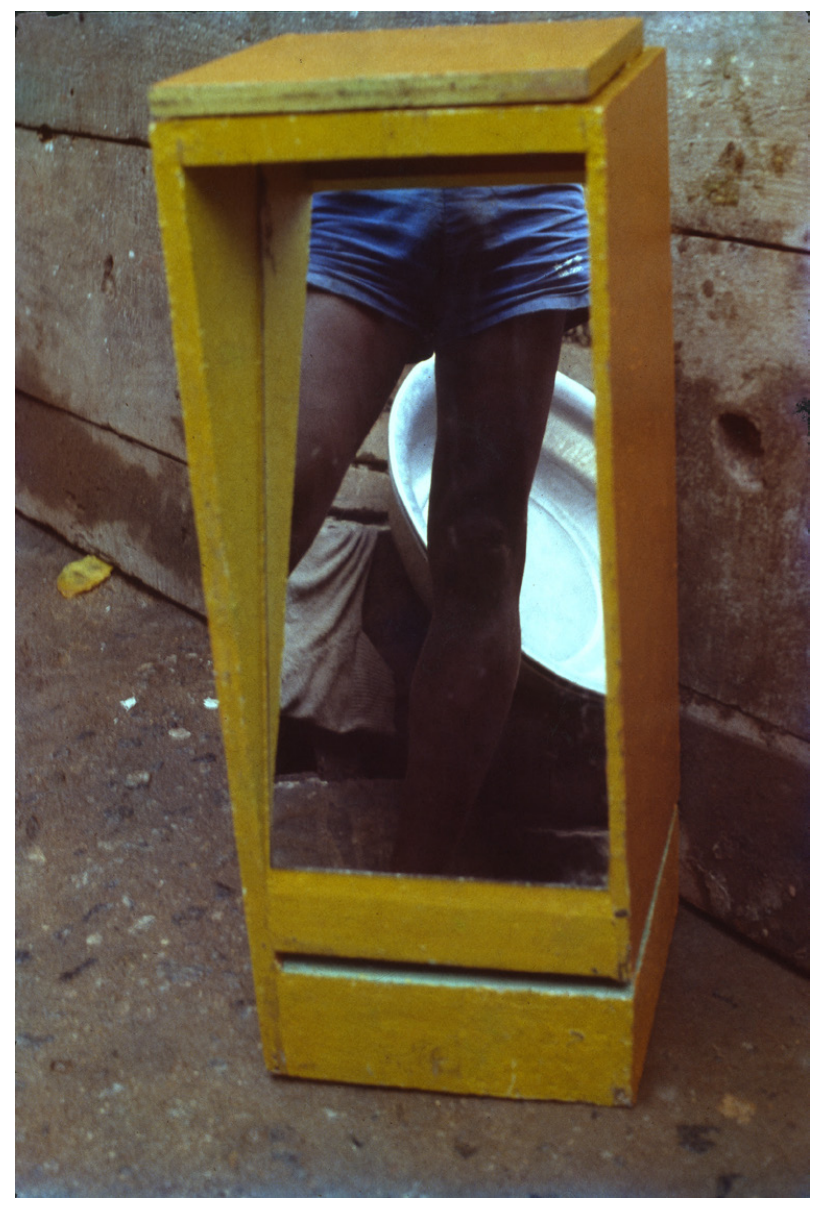

Em fevereiro de 1980 voltamos novamente à Mangueira para realizar o Esquenta para o Carnaval. Foi o segundo ACONTECIMENTO POÉTICO-URBANO (o primeiro havia sido KLEEMANIA, no bairro do Caju) planejado por Hélio como ação coletiva, para "inventar um paralelo poético ao Carnaval", não "algo dentro do samba, mas paralelo a ele". ${ }^{31}$ Fiz ali fotografias com Hélio e Paulo Ramos vestindo um Parangolé feito especialmente para o Esquenta.

Algumas semanas depois viajei para Manaus onde fui morar com a família. No final de março chegou a notícia de que ele havia sofrido um derrame em seu apartamento no Leblon. Foi encontrado por Lygia Pape ainda lúcido dois dias depois. Ela e eu éramos as duas pessoas que tinham a chave de seu apartamento. Ele nos dissera premonitoriamente: "se vocês telefona-

31 Itaú Cultural, Programa Hélio Oiticica, AHO/PHO 0047/80. 
Figura 18

Hélio Oiticica e

Paulo Ramos na quadra da Mangueira no Esquen-

ta para o Carna-

val. (Foto Andreas

Valentin, 1980).

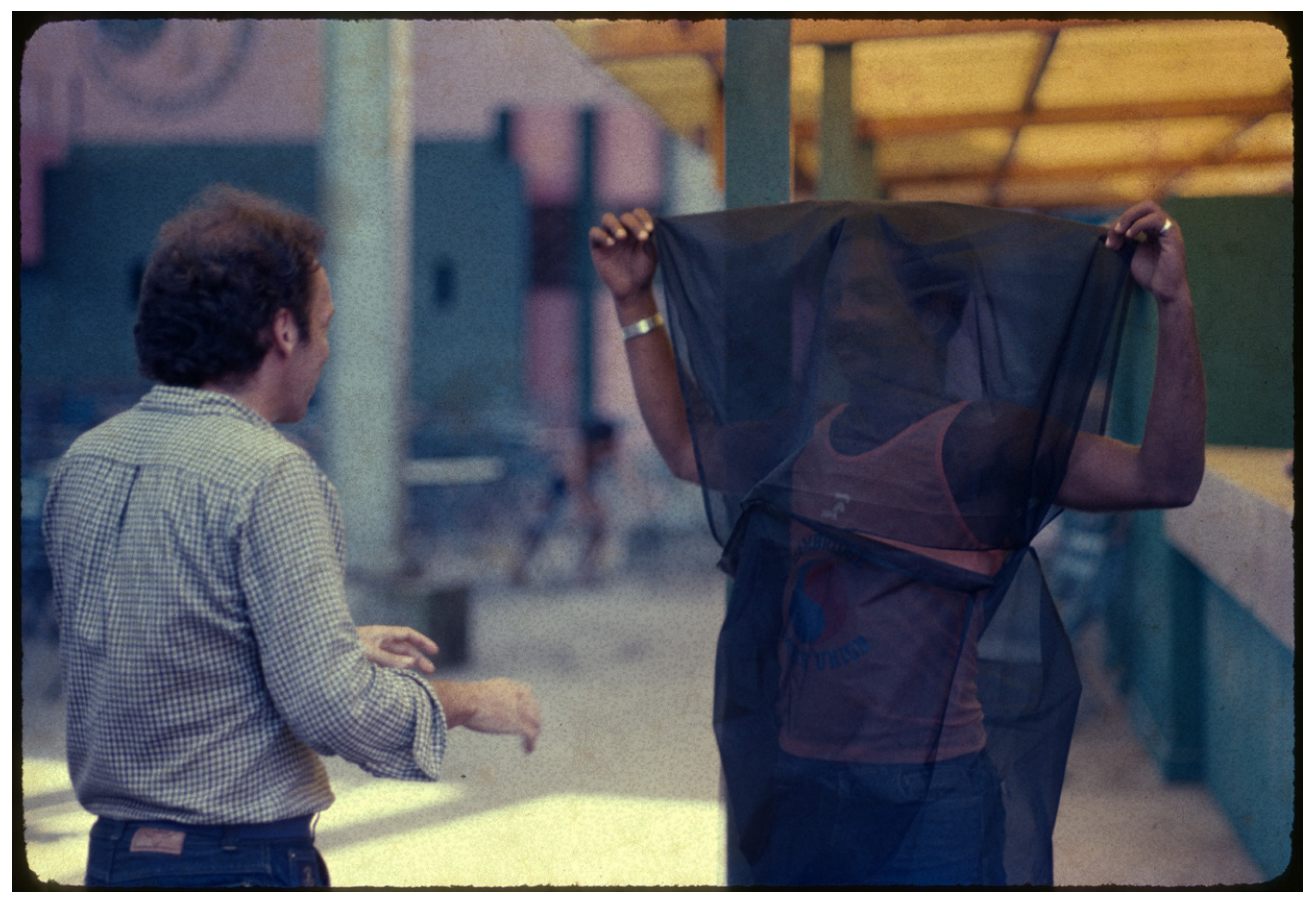

rem ou passarem aqui e após um dia eu não atender, venham porque algo deve ter acontecido".

Hoje, 40 anos após sua morte, penso que seu grande legado, além de sua magnífica obra, talvez seja justamente a imensa - e generosa - capacidade de juntar pessoas, assuntos, coisas e ideias: conectar, inventar e fazer. Como ele próprio declarou, aprendeu com Ivan Serpa que "melhor não fazer, do que fazer o que não se quer".

Este é um artigo publicado em acesso aberto sob uma licença Creative Commons $(\mathbf{c c}) \mathbf{B} \mathbf{B r}$ 